\title{
Erratum to: Volume 1, Contraception and Reproductive Medicine
}

\author{
Contraception and Reproductive Medicine
}

Due to a technical issue with the set-up of the journal Contraception and Reproductive Medicine in production, the articles [1-5] were published with the incorrect volume and year information in the PDF of the article. In the HTML versions of the articles [1-5], the articles were published with incorrect volume information. The articles [1-5] were published into volume 2 and year 2017; however they should have been published in volume 1 and year 2016.

Each article [1-5] has since been updated with the correct volume and year information and is also listed with the correct information in the references in this erratum.

The publisher takes full responsibility for this error and sincerely apologises for the inconvenience caused.

Received: 14 March 2016 Accepted: 17 March 2016

Published online: 14 April 2016

\section{References}

1. Shepherd R, Raker CA, Savella GM, Du N, Matteson KA, Allen RH. The effect of obesity on intraoperative complication rates with hysteroscopic compared to laparoscopic sterilization: a retrospective cohort study. Contraception and Reproductive Medicine. 2016;1:1. doi:10.1186/s40834016-0008-3.

2. Amu H, Nyarko SH. Trends in contraceptive practices among women in reproductive age at a health facility in Ghana: 2011-2013. Contraception and Reproductive Medicine. 2016;1:2. doi:10.1186/s40834-016-0010-9.

3. Bartz D, Paris A, Maurer R, Gardner R, Johnson N. Medical student simulation training in intrauterine contraception insertion and removal: an intervention to improve comfort, skill, and attitudes. Contraception and Reproductive Medicine. 2016;1:3. doi:10.1186/s40834-016-0009-2.

4. Shoupe. LARC methods: entering a new age of contraception and reproductive health. Contraception and Reproductive Medicine. 2016; 1:4. doi: 10.1186/s40834-016-0011-8.

5. Atuahene MD, Afari EO, Adjuik M and Obed S. Health knowledge, attitudes and practices of family planning service providers and clients in Akwapim North District of Ghana. 2016; 1:5. doi: 10.1186/s40834-016-0016-3.

* Correspondence: crm@biomedcentral.com

BioMed Central, Floor 6, 236 Gray's Inn Road, London WC1X 8HB, UK

Submit your next manuscript to BioMed Central and we will help you at every step:

- We accept pre-submission inquiries

- Our selector tool helps you to find the most relevant journal

- We provide round the clock customer support

- Convenient online submission

- Thorough peer review

- Inclusion in PubMed and all major indexing services

- Maximum visibility for your research

Submit your manuscript at www.biomedcentral.com/submit \section{.}

